\title{
Planned Behavior and Intention to Study Abroad Concerning Family Rally Relationship: Case in Vietnam
}

\author{
Phuong Huu Tung, Nguyen Nghi Thanh, and Nguyen Anh Nguyet
}

\begin{abstract}
Vietnamese students studying abroad in recent years have received worldwide attention. This study explores the relationship between planned behaviour, i.e., attitude towards behaviour, subjective norm and perceived behavioural control and coherence towards intention to enrich the literature Vietnamese students studying abroad at university. In addition, the study also explores the factors related to family cohesion to the intention of Vietnamese students to study abroad. This study was conducted through a cross-sectional survey using a targeted sampling technique $(n=350)$. The SEM model was used to test the hypotheses. The SEM model proved that: The decisive factor affects the intention to study abroad with the coefficient of Regression Weight $=\mathbf{0 . 2 2 2}$. The subjective norm factor (norm) affects the intent variable with the coefficient of Regression Weight $=0.138$; The behavioural intention control factor affects the intent factor with Regression Weights $=0.276$; The factor through family cohesion (cohesion) affects the intent factor with Regression Weights $=0.159$. The conclusions of this study provide valuable data for study abroad managers, universities, study abroad consulting service providers, and families who want to invest in their children to study abroad.
\end{abstract}

Index Terms - family relationship cohesion, intention, student, study abroad, theory of planned behavior, university, Vietnam.

\section{INTRODUCTION}

The Open Doors report of the Institute of International Education (IIE) shows that in the 2017-2018 school year, Vietnam continued to rank 6th in the list of leading countries in the number of university students in the United States, with 24,325 students, an increase of $8.4 \%$ [1]. Vietnam is a promising market for foreign educational institutions and universities to increase enrollment [1]. Only about $10 \%$ of people who study abroad are funded, about $90 \%$ study abroad on their own every year. In 2018, Vietnam became one of the top countries to send students abroad. Japan is the top host country for Vietnamese students, with 61,671 students in 2017, followed by the United States with 31,613 students, Australia with 23,000 students, and Canada with around 15,000 students. During the 2016-2017 school year, Vietnamese students attending colleges and universities in the United States contributed $\$ 818$ million to the country's economy [2]. In 2017, the amount of money that Vietnamese study abroad contributed accounted for $4.1 \%$ of the total money of international students in Australia. At the same time, the amount of money that Vietnamese study abroad contributed nearly 400 million USD to the UK economy.

Published on August 21, 2021

Dr. Phuong Huu Tung, Hanoi University of Home Affairs, Vietnam. (corresponding e-mail: phuonghuutung ${ }^{@}$ gmail.com)

Dr. Nguyen Nghi Thanh, Hanoi University of Home Affair, Vietnam.

(e-mail: thanhnndhnv@gmail.com)
The Japan Student Services Organization (JASSO) found that in $2107,61,671$ Vietnamese students went to Japan to study, an increase of $14.6 \%$ compared to 2016.

There are many different research approaches on the factors affecting students' intention to study abroad. Researchers divide the factors affecting the decision to study abroad into factors that are divided into push factors and pull factors [3]. Push factors include the unavailability of a desired program of study, the lack of access to universities, and the poor quality of education in the host country [3]. Pull factors include the host country's culture, the standard of living, socioeconomic status, improved career prospects, and immigration opportunities [3]. An international student's decision to study abroad can be influenced by family, teacher, and other socioeconomic, political, and cultural issues in the host country and host country [4]. In addition, the factors affecting students' intention to study abroad include the student's parents, previous personal international travel experience, family income, course costs, local commitments to arrange a study abroad program, scheduling work or activities, getting out of the loop, relationships with family and friends [5].

Leung [6] and World Bank [7] said that due to rapid socioeconomic growth, the proportion of students studying abroad increased rapidly. World Bank [8] argues that higher education has been expanded and reformed to produce more graduates with appropriate qualifications and competencies to meet needs in the labour market and achieve the socioeconomic goals set by the government. The university system does not seem to respond to the more considerable demand for higher education [9]. In addition, [9] and [10] attributed it to increasing concerns about the poor quality of the higher education system in Vietnam. Because employers are not satisfied with the quality of Vietnamese university graduates, they tend to favour graduates from foreign [11].

There is also the commitment of the Vietnamese government to send Vietnamese students abroad and the presence of many international educational groups or organizations that have contributed to promoting the value of the international educational experience.

As a result, there has been an increase in Vietnamese students sent abroad to obtain international education for better career prospects and to achieve personal growth.

According to studies on the factors affecting the intention to study abroad of Vietnamese people mainly discovered the impact of pull factors and push factors.

Nguyen Anh Nguyet, Hanoi University of Home Affairs, Vietnam. (e-mail: nguyetna.tckhnv@ ${ }^{@}$ gmail.com) 
Pull factors include foreign cultural experience; gain international experience; establish relationships with international friends; improve foreign language ability; improve international employment opportunities; pursue foreign educational values. Push factors include competition of higher education in Vietnam; the desired university program is not yet available; avoid contact that is not close to reality in Vietnamese education; was decided by the family to study abroad; pursue immigration opportunities; The quality of education is not good in Vietnam. Real-life experience and studying in a host country are rewarding learning experience for Vietnamese students. The number of students going abroad to pursue international education has continuously [12]; [13].

There is currently a lack of quantitative studies examining individual factors affecting the intention of Vietnamese students to study abroad. This study explores the relationship between factors in the theory of planned behaviour and family cohesion on the intention of Vietnamese students to study abroad.

\section{THEORETICAL BACKGROUND}

\section{A. Theory of Planned Behavior}

The theory of planned behaviour (TBP) is an extension of the theory of reasoned action (TRA) [14], [15] used to predict individual behaviours. TPB has been beneficial in predicting and understanding human behaviour [14], [16], [17]. This theory's main objective examines, predicts, and explains one's behaviour (Fig. 1).

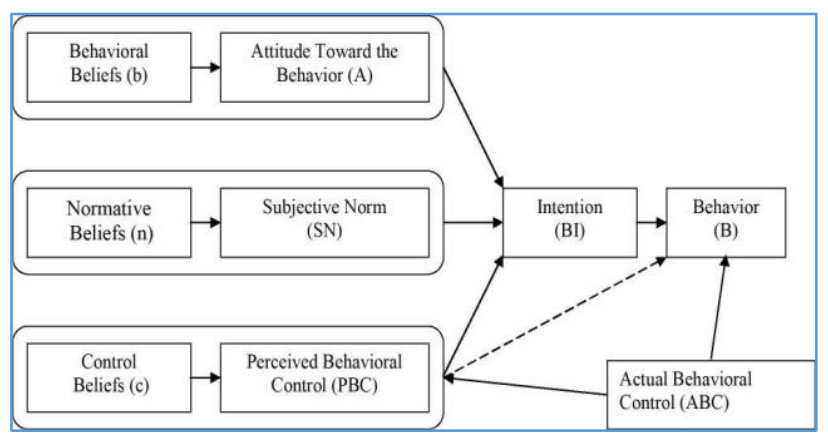

Fig. 1. Theory of planned behavior [17].

According to Ajzen [18], human behaviour is guided by three types of considerations: beliefs about possible consequences of behaviour (Behavioral Beliefs), beliefs about the normative expectations of others (Normative Beliefs).

Moreover, beliefs about the presence of factors that can facilitate or hinder the performance of the behaviour (Control Beliefs).

Behavioural Belief is the subjective probability that a behaviour will produce a specific outcome. Behavioural beliefs are based on personal experiences, sources of information, and inferences. The salient beliefs must be easily accessible in memory. Pilot work is needed to identify accessible behavioural beliefs, rules, and controls. In their respective set, behavioural beliefs create an attitude towards favourable or unfavourable behaviour [18]. Behavioural
Belief is an individual's perception of the possible consequences of performing a behaviour [19].

Normative Beliefs involve social pressures social pressure towards perceived subjective norms [18]. Control Beliefs give rise to behavioural control or self-efficacy [18]. The effects of attitude towards behaviour and subjective norms on intention are moderated by perceived behavioural control [18]. As a general rule, the more favourable the attitude toward the behaviour and subjective norm, and the greater the perceived control, the more likely the person intends to perform the behaviour in question. Finally, with a realistic degree of control over behaviour, people are expected to fulfill their intentions when given the opportunity. Therefore, intention is considered as the antecedent of behaviour. To the extent that perceived behavioural control is reasonable, it can act as a proxy for actual control and contribute to predicting the behaviour in question.

Control Beliefs are the antecedents of cognitivebehavioural control. Controlling beliefs must be exercised in the perceived presence of factors that may facilitate or hinder the performance of the behaviour [15]. Each control factor has a perceived strength associated with it, and this contributes to behavioural control in direct proportion to a person's subjective probability that that control element is present [15]. Accessible factors affecting control beliefs can be identified by creating a list of factors that can facilitate or hinder the performance of a particular behaviour [15].

Attitude Toward behaviour is formed by a personal judgment, whether positive or negative, about the expected outcome of performing a behaviour [19].

Subjective norm is the perceived social pressure to engage or not engage in a behaviour [15]. The subjective norm is assumed to be determined by the total number of accessible normative beliefs regarding the significant referrer's expectations. In particular, the strength of each normative belief is weighed by the motivation, adherence to the referrer in question and the products aggregated [15]. Subjective norm is an individual's perception of a particular behaviour and the strength of the motivation to conform or conform, given the beliefs of others involved [19]. An individual behaviour carried out rationally is characterized by straightforward decision-making processes [20].

Perceived Behavioral Control refers to people's perception of their ability to perform certain behaviours [15]. The structure includes the ease or difficulty with which a person relates to a particular task or behaviour. In TBP, cognitive behavioural control is defined by the total accessible control of factors supporting or hindering behavioural performance. Perceived behavioural control is an individual's assessment of an individual's ability to engage in an intended behaviour based on his or her perceived ability or perceived difficulty or ease in performing the behaviour [19]. The intention is defined by attitudes toward behaviour, subjective norms, and perceived behavioural control [15], [17].

The intention is considered a motivational variable and a context-specific representative of goal-directed behaviour [21].

Various studies have examined the relationship between intention and behaviour in different domains and suggest that intention is an essential behavioural predictor [22].

Some of the conditions that must be met to predict 
behavioural control accurately and behavioural intentions are that the intention and perceived behavioural control must correspond to or be compatible with the intended behaviour and must be shared context [17]. Intention and perceived behavioural control must remain stable between behavioural evaluation and observation [17]. To have a higher predictive validity, perceptions of behavioural control must reflect actual control [17]. Behavioural intention is an indication of a person's willingness to perform a particular behaviour or action. Behavioural intention is considered as the antecedent of behaviour. This intention is based on attitudes toward behaviour, subjective norms, and behavioural controls, with each predictor weighted for its importance relative to the behaviour and population of interest [15].

Behavioural intention indicates the level of effort and complex work individuals are willing to perform the behaviour [17], [15]. Intention prediction can be achieved through three determinants: attitude towards behaviour, subjective norm, and perceived behavioural control [23].

Human behaviour is stimulated by behavioural intentions, influenced by underlying beliefs [24]. Human behaviour revolves around the intention to capture the factors that influence behaviour and favour people's actions. Identifying and understanding motivational, behavioural factors is crucial in understanding why an individual engages in a behaviour to change behaviour in society [25]; [26].

The absence of studies applying the theory of planned behaviour to explore the factors affecting the intention of Vietnamese students to study abroad is a shortcoming that needs to be supplemented. They can explore the relationship between the theory of planned behaviour and the intention to study abroad, and this study poses the following research hypotheses:

H1. Vietnamese students' perception of the benefits of studying abroad has a positive and meaningful impact on Vietnamese students' intention to study abroad.

H2. The influence of people around has a positive and meaningful impact on the intention of Vietnamese students to study abroad.

H3. The ability to control study abroad factors positively and significantly affects the intention of Vietnamese students to study in university.

H4. Family ties have a positive and significant impact on Vietnamese students' intention to study abroad.

\section{B. Family Bonding}

Previous studies have explored how family members have linked in meaningful ways across life stages and that these relationships are an essential source of social connection and social influence for individuals throughout their lives. There is significant evidence that family relationships can profoundly affect people's lives. Family connections can provide greater meaning and purpose and social and tangible resources conducive to well-being [27], [28]. Much research on the parent-child relationship has a significant impact on children's transition during adulthood [29], [30].

Students make dramatic life changes such as completing school, entering long-term romantic and marriage relationships, and starting careers [31]. Their family relationships greatly influence students' decisions about their future, specifically their relationships with their parents and siblings [32]-[35].

The closeness and warmth, intimacy, and attachment of parents to their children, and support greatly influence the future intentions of students from their parents [29]; [36]. In contrast, the relationship between parents and their children has more conflict and tension, less affection, leading to a higher rate of conflict in their relationship with their children, ants have less influence. their influence on their children's future intentions [29]. Stress undermines health and wellbeing. Family members can also regulate each other's behaviours (e.g., social control) and provide information and encouragement to behave in healthier ways. Therefore, family relationships are the basis for predicting students' decisions after high school [29], [37]; [33].

Regarding the relationship between intention to study abroad and family cohesion, [38] explored the family factors affecting students' intention to study abroad, including finance, information, expectations, theory, and competition (finance, information, persuasion, and competition). The views of family members can lead to many kinds of influences on an individual's behaviour, and encouragement from a family back home becomes an essential factor to be considered when making decisions determined [38]. Family encouragement is an essential factor to be considered when making a student's decision to study abroad [39]. Similarly discovered that family ties and intention to study abroad in students' lives are thought to influence the choice of the host country for students to pursue higher education. The family has a positive influence on a student's intention to study abroad. In particular, family opinions influence students' choices of their overseas educational institutions [40]. Family advice strongly influences students' intention to study abroad [41]. Information and support from the family is a factor of the belief that strongly influences individual cognition [42]. Economic factors of the family affect students' intention to study abroad. The student's choice of country and institution of higher education depends on their family's financial condition or financial aid in the form of scholarships or tuition waivers [43].

Encouragement from a family back home becomes a vital factor to consider while making decisions [39]. Suggestions and perspectives from families and individuals closest to students' lives are believed to influence the host country's choice to pursue higher education. Whether with family, relatives or friends in the destination country, social relationships can influence a student's intention to study abroad [44].

Information and support from the family are considered an influential factor of beliefs that affect individual cognition [3], [38], [42].

Previous research has shown that while students make decisions about their destination country based on their knowledge, that of family and friends' feedback and discussion influences their perceptions of universities and the country indirectly [3], [38], [42].

Vietnam has a tradition of family members helping and supporting each other, spending much time working together, creating a feeling of closeness and mutual support Individuals are an essential part of a family that gets along with each other. Therefore, when students decide to study abroad, there is often feedback and discussion from their 
families [45]. The career orientation of parents towards their children in the family is a meaningful thing in the future career development of their children [45]. In Vietnam, the family plays a significant role in forming professional qualities for children [46]. Some admitted that they did not want to study abroad, but their family asked them to seek immigration opportunities. Therefore, we put forward the following hypothesis.

\section{MATERIALS AND METHODS}

\section{A. Variables and Measures}

A self-assessment questionnaire was developed after consulting with experts in the field of education. After completing the questionnaire, we conducted a survey and analyzed the trial with adjustment. The questionnaire consists of three parts: a population information survey including gender, status of having lived abroad, a theory of planned behaviour, and a question about family cohesion (Table I). Items on family cohesion are partially inherited from The Brief Family Relationship Scale questionnaire. Each item is measured on a 5-point Likert scale (Disagree strongly $=1$; Disagree a little $=2$; Neither agree nor disagree $=3$; Agree a little $=4$; Agree Strongly $=5$ ). Chart I. Items in the questionnaire (Appendix I).

\section{B. Data Collection}

The design used for the study is a cross-sectional survey design that aims to measure the independent variables considered as factors affecting students' intention to study abroad.

The study was conducted in high schools in Hanoi city in June 2019. Intentional sampling method. Collect data through a questionnaire survey of $350(n=350)$ students.

Respondents mark items into the appropriate choices with a pencil. Collected data were analyzed using SPSS 2.0 and SPSS AMOS 2.0 software, so fifty faulty questionnaires were discarded. Only 300 questionnaires remained to be included in the analysis. Demographic information, including gender and previous living abroad status is depicted in Table I.

\begin{tabular}{|c|c|c|c|c|c|}
\hline Factor & Items & Male & Female & Total & Percent \\
\hline \multirow{2}{*}{$\begin{array}{c}\text { Previous } \\
\text { international } \\
\text { living }\end{array}$} & $\begin{array}{c}\text { No previous } \\
\text { international } \\
\text { living }\end{array}$ & 118 & 129 & 247 & 82.3 \\
\hline & $\begin{array}{l}\text { Lived } \\
\text { abroad }\end{array}$ & 22 & 31 & 53 & 17.7 \\
\hline \multirow{3}{*}{$\begin{array}{c}\text { Parental } \\
\text { occupation }\end{array}$} & $\begin{array}{c}\text { Government } \\
\text { worker }\end{array}$ & 59 & 60 & 119 & 39.7 \\
\hline & $\begin{array}{c}\text { Small } \\
\text { business }\end{array}$ & 29 & 38 & 67 & 22.3 \\
\hline & Entrepreneur & 52 & 62 & 114 & 38.0 \\
\hline
\end{tabular}

The results in Table I show that 140 male students and 160 female students participated in answering the question. Among them, 247 students admitted that they had not lived abroad. There were 53 students admitted to having lived abroad. The results in Table I show that 118 male students admitted to having never lived abroad in the past. Twentytwo male students admitted to having lived abroad during the previous period, and 129 female students admitted that they did not live abroad in the previous period, and finally, thirty- one female students admitted to having lived abroad during the previous period.

\section{RESUlts}

\section{A. Reliability Analysis}

Chart 3 shows that the Cronbach's Alpha coefficient of all items is more significant than 0.8 , enough to analyze the next steps [47]. Good composite reliability for a defined construct with five to eight items to meet the minimum threshold of 0.80 . Table II items have aggregate confidence greater than 0.8 . Thus, the items in Table II all meet the requirements to analyze the next steps. The threshold for accepting variance extracted (Average Variance Extracted) of items greater than 0.50 is satisfactory [47]; [48]. Table II shows that the combined reliability of the items is approximately 0.6 . Thus, satisfying the requirements for the analysis of the following steps.

TABLE II. RELIABILITY ANALYSIS

\begin{tabular}{cccc}
\hline \multicolumn{3}{c}{ TABLE II. RELIABILITY ANALYSIS } \\
\hline \hline Factors & $\begin{array}{c}\text { Cronbach } \\
\text { alpha }\end{array}$ & $\begin{array}{c}\text { Average } \\
\text { Variance } \\
\text { Extracted }\end{array}$ & $\begin{array}{c}\text { Composite } \\
\text { Reliability }\end{array}$ \\
\hline Cohesion & 0.921 & 0.595 & 0.921 \\
Attitude & 0.890 & 0.600 & 0.882 \\
Norm & 0.892 & 0.581 & 0.893 \\
Control & 0.894 & 0.586 & 0.891 \\
Intent & 0.900 & 0.600 & 0.899 \\
\hline \hline
\end{tabular}

\section{B. Factor Analysis}

The condition for exploratory factor analysis is to satisfy the following requirements: Factor loading $>0.5$. $0.5 \leq \mathrm{KMO}$ $\leq 1$ : KMO coefficient (Kaiser-Meyer-Olkin) is an index used to consider the suitability of factor analysis. Table III shows that the Bartlett test has statistical significance (Sig.=0.00), coefficient $\mathrm{KMO}=0.944$. The large KMO coefficient means that factor analysis is appropriate. Bartlett test has statistical significance (Sig. < 0.05): This is a statistical quantity used to consider the hypothesis that variables do not correlate in the population if this test is statistically significant (Sig. < 0.05), the observed variables are correlated with each other in the population. Thus, the variables are valid for factor analysis. Table V shows that the Extraction Sums of Squared Loadings of 5 factors $=62.848 \%$ are valid [47]. Initial Eigenvalues of 5 factors $=1,902$ (greater than 1.40) are valid.

\begin{tabular}{ccc}
\multicolumn{3}{c}{ TABLE III. KMO AND BARTLETT'S TEST } \\
\hline \multicolumn{2}{c}{$\begin{array}{c}\text { Adequacy. } \\
\text { Kaiser-Meyer-Olkin Measure of Sampling }\end{array}$} & 0.944 \\
& Approx. Chi- & 5601.048 \\
Bartlett's Test of & Square & 496 \\
Sphericity & df & 0.000 \\
\hline
\end{tabular}

Factor loading (factor loading factor or factor weight) is the criterion to ensure the practical significance of factor analysis: Factor loading $>0.3$ is considered to be the minimum level; Factor loading $>0.4$ is considered necessary; Factor loading $>0.5$ is considered to be of practical significance. Appendix II shows that the factor loading of all variables is more significant than 0.7 , which means that the factor analysis is valid [49]. Total variance explained 
(Appendix II).

\section{Structural Equation Modeling (SEM)}

The SEM model is an extension of the general linear model (GLM) that allows the researcher to test a set of regression equations simultaneously. The SEM model combines all the techniques such as multivariate regression, factor analysis and correlation analysis (between elements in the network diagram) to check the complex relationship fit in the model. Unlike other statistical techniques that only allow estimation of the partial relationship of each pair of factors (elements) in the classical model (measurement model). SEM allows the simultaneous estimation of the elements in the model, the overall model estimates the causal relationship between the latent concepts (Latent Constructs) through indicators that combine both measurement and structure of the theoretical model, measure the stable relationships (recursive) and nonrecursive, measuring direct and indirect effects, including measurement error and residual correlation. With the confirmatory factor analysis (CFA) technique, the SEM model allows the flexibility to find the most suitable model in the proposed models [50]-[54].

To evaluate the fit of the SEM model, a Chi-Square $(\chi 2)$ test, Root-Mean-Square Error of Approximation (RMSEA) procedure together with a confidence interval, standardizedroot-mean, is required square residual (SRMR), TuckerLewis Index (TLI) (Tucker \& Lewis, 1973), and Comparative Fit Index (CFI) [55] were reported. It is suggested that a good fitting model should have values of CFI and TLI $\geq 0.90$, RMSEA and SRMR $\leq 0.08$ [56], [51].

TABLE IV: ROTATED COMPONENT MATRIX

\begin{tabular}{|c|c|c|c|c|c|}
\hline & \multicolumn{5}{|c|}{ Component } \\
\hline & 1 & 2 & 3 & 4 & 5 \\
\hline Cohension4 & .783 & & & & \\
\hline Cohension2 & .779 & & & & \\
\hline Cohension 3 & .776 & & & & \\
\hline Cohension1 & .757 & & & & \\
\hline Cohension6 & .756 & & & & \\
\hline Cohension5 & .749 & & & & \\
\hline Cohension7 & .742 & & & & \\
\hline Cohension8 & .736 & & & & \\
\hline Int4 & & .798 & & & \\
\hline Int3 & & .782 & & & \\
\hline Int6 & & .767 & & & \\
\hline Int 1 & & .756 & & & \\
\hline Int 2 & & .734 & & & \\
\hline Int5 & & .718 & & & \\
\hline Con3 & & & .757 & & \\
\hline Con4 & & & .748 & & \\
\hline Con1 & & & .743 & & \\
\hline Con 2 & & & .740 & & \\
\hline Con6 & & & .738 & & \\
\hline Con5 & & & .736 & & \\
\hline Nor6 & & & & .794 & \\
\hline Nor4 & & & & .762 & \\
\hline Nor5 & & & & .751 & \\
\hline Nor2 & & & & .734 & \\
\hline Nor3 & & & & .715 & \\
\hline Nor1 & & & & .706 & \\
\hline Ati6 & & & & & .793 \\
\hline Ati3 & & & & & .742 \\
\hline Ati5 & & & & & .731 \\
\hline Ati1 & & & & & .731 \\
\hline Ati4 & & & & & .705 \\
\hline Ati2 & & & & & .702 \\
\hline
\end{tabular}

Extraction Method: Principal Component Analysis. Rotation Method: Varimax with Kaiser Normalization. a. Rotation converged in 6 iterations.
The results of SEM analysis (Fig. 2.) show that the attitude factor affects the intent multiplier with the coefficient of regression Weight $=0.222$ with significance $(p$-value $=0.08)$.

Vietnamese students' perception of the benefits of studying abroad has a positive and significant impact on Vietnamese students' intention to study abroad.

The subjective norm factor (norm) affects the intent variable with a coefficient of 0.138 and has a significant level $(\mathrm{p}$-value $=0.027)$. Therefore, hypothesis H2. The influence of people around has a positive and meaningful impact on the intention of Vietnamese students to study abroad.

The behavioral intention control factor (control) affects the intent factor with Regression Weights $=0.276$ and has a significance level ( $\mathrm{p}$-value $=0.00$ ). Therefore, hypothesis H3. The ability to control factors to study abroad has a positive and significant impact on the intention of Vietnamese students to study in university if accepted.

The factor through family cohesion (cohesion) affects the intent factor with Regression Weights $=0.159$ and has significance $(p$-value $=0.002)$. Therefore, hypothesis H4 Family ties have a positive and significant impact on Vietnamese students' intention to study abroad.

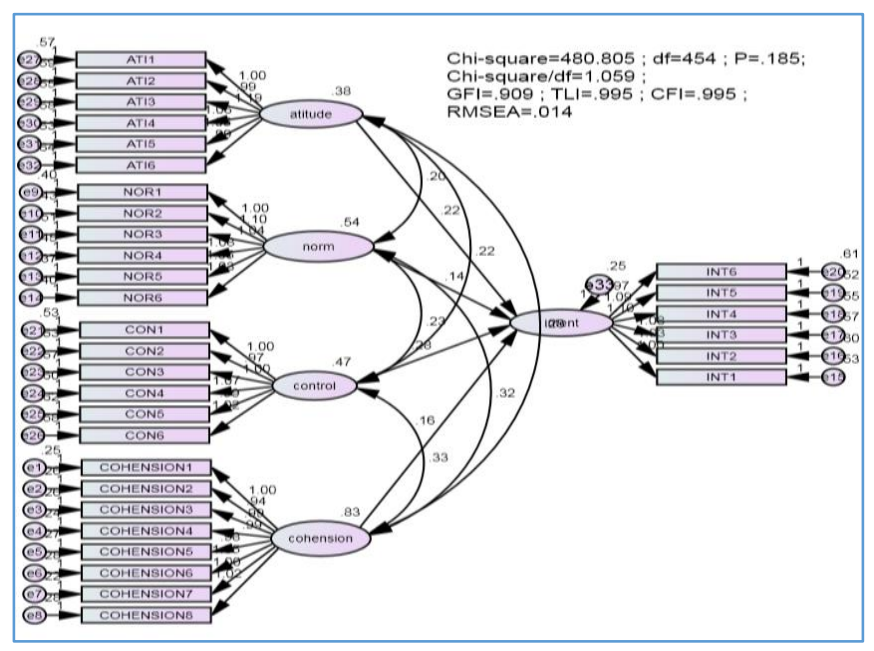

Fig. 2. Analysis results sem.

TABLE V: REGRESSION WEIGHTS

\begin{tabular}{lcccccc}
\hline & & EST & S.E. & C.R. & P & \\
\hline Intent & Atitude & .222 & .084 & 2.635 & .008 & accept \\
Intent & Cohension & .159 & .052 & 3.077 & .002 & accept \\
Intent & Control & .276 & .078 & 3.511 & $* * *$ & accept \\
Intent & Norm & .138 & .062 & 2.217 & .027 & accept \\
\hline
\end{tabular}

The model verification coefficients satisfy the standard requirements of the SEM model (Fig 2): Chi-square = 480,805; Df = 454; P-value = 0.185; Chi-square $/ \mathrm{df}=1,059$; $\mathrm{GIF}=0.909 ; \mathrm{TLF}=0.995 ; \mathrm{RMSEA}=0.014[56]$.

\section{DISCUSSION}

\section{A. Key Findings}

Firstly, the study found a relationship between Vietnamese students' perception of the benefits of studying abroad, which has a positive and significant impact on Vietnamese students' intention to study abroad. Vietnamese students already have an attitude of awareness about the benefits, advantages, and disadvantages of studying abroad before deciding to study 
abroad. It is a perception that affects behavioural intentions [56].

The findings of this study coincide with the findings of [57] that students intending to study abroad perceive cultural motivations, information resources, and achievement motivations that affect their intention to study abroad [57].

Previous research also discovered that students are aware that studying abroad will directly experience and discover new things, have access to an advanced civilization, culture, and society, especially enjoy an advanced and modern education, have contact with many friends from all over the world [57].

Second, the study found a relationship between the impact of people around on the intention of Vietnamese students to study abroad. Ajzen [15] states that the subjective norm is the perceived social pressure to engage or not to engage in a behaviour [15]; [19]. It is similar to previous studies that found that Vietnamese students belong to vulnerable families and are heavily affected by social pressure to study abroad [58]. Exploring the factors affecting Vietnamese students' intention to study abroad, [57] found that social pressure is a positive and significant factor affecting the decision to study abroad. With the pressure of education in the country and recognition of development opportunities, many families have oriented their children to study abroad since they were in middle school and high school, and a large number of them, even though they passed university, study but still decide to study abroad. Some admitted that they did not want to study abroad, but their family asked them to seek immigration opportunities.

Third, the study finds a relationship between the ability to control factors to study abroad that has a positive and significant impact on the intention of Vietnamese students to study in university.

Students assess their ability to participate in university study abroad behaviour based on cognitive ability on their own [19]. As mentioned above, controlling beliefs must be exercised in the perceived presence of factors that can facilitate or hinder the performance of the behaviour [15]. Each control factor has a perceived strength associated with it, and this contributes to behavioural control in direct proportion to a person's subjective probability that that control element is present [15]. Economic factors of the family affect students' intention to study abroad.

Fourth, the most critical finding is that family ties positively and significantly impact Vietnamese students' intention to study abroad. As mentioned above, Vietnam has a tradition of family members that value helping and supporting each other, spending much time working together, creating a feeling of closeness and mutual support. Individuals are an essential part of a family that gets along with each other. Therefore, when students decide to study abroad, there is often feedback and discussion from their families [45]. The career orientation of parents towards their children in the family is a crucial and meaningful thing in the future career development of their children [45]. In Vietnam, families play a significant role in shaping the professional qualities of their children [46]. It is similar to previous studies of [37], [33]. Family relationships are the basis for predicting students' decisions after they graduate from high school. Similarly, it was found that family encouragement is an important factor to be considered when making a student's decision to study abroad [39]. Family has a positive influence on the student to study abroad. In particular, family opinions influence students' overseas educated family institutions [40]. Family advice strongly influences students' intention to study abroad [41]. Information and support from family are factors of beliefs that strongly influence individual cognition.

Fifth, this study explores the impact of two factors, attitude, and control, because these two factors have the most substantial impact on the intention of Vietnamese students to study abroad. It proves that the university study behaviour of Vietnamese students is mainly influenced by their perception of the benefits of studying abroad and their ability to perform study abroad behaviour. The factors related to family cohesion (cohesion) and behavioural control (norm) affect the intention to study abroad at a low level, proving that in today's society, the role of social pressure, The role of the family no longer influences students' decisions to study abroad.

In summary, this study explored the intention of Vietnamese students to study in university as determined by attitudes towards behaviour, subjective norms and perceived behavioural control [17], [15].

Based on the theory of planned behaviour and family cohesion (cohesion), this study focuses on the effects of attitudes on intention to study abroad, subjective norms, control behaviour and family cohesion on intention to study abroad. Future research should combine cross-sectional and longitudinal studies. Attitudes on intention to study abroad, subjective norms, control behaviour and family cohesion on intention to study abroad. In the research model, several other factors have been ignored, such as the impact of parents' finances, demographic characteristics that may have on their intentions and behaviour in the model-our picture.

Going to college is a motivational variable and a contextspecific representative of goal-directed behaviour [21]. Studying abroad is a significant predictor of college student behaviour [22]. This conclusion helps us form a complete understanding of Vietnamese students' intention to study abroad. These findings have important implications for policymakers, universities, businesses, and agencies providing study abroad counselling and students' families. In addition, this study contributes additional research data to the theoretical model of planned behaviour by determining the significant effects of the variables in the research model.

\section{B. Implications}

Study abroad managers, consulting service providers, and students' families who want to study abroad for their children should consider their perception, behaviour control, subjective standards, and attitudes for university study abroad behaviour to determine the following steps to send students abroad to study. In considering the perception, behavioural control, subjective standards, and attitudes towards university study abroad behaviour, it is necessary to focus on attitude (attitude) and control behaviour because these two factors affect the most substantial influence on the intention to study abroad. In addition, it is also necessary to pay attention to the factors of family cohesion (cohesion) and behavioural control (norm). However, the impact of these two factors on the intention to study abroad is not high. Education initiatives in Vietnam should have a marketing campaign to influence 
study abroad beliefs and attitudes towards the behaviour and values of studying abroad.

The role of family cohesion on students' intention to study abroad has little impact on student's intention to study abroad, raising the role of the family in children's careers. This finding is similar to Tran's 2019 finding that some people admit they do not want to study abroad, but their families ask them to seek immigration opportunities. Previous studies have discovered that family plays a crucial role in shaping career qualities for children [46]. The career orientation of parents towards their children in the family is a vital and meaningful thing in the future career development of their children [45]. Therefore, it is necessary to re-evaluate the role of members in children's decisions, especially the role of parents.

\section{Limitations}

As with other empirical studies, there are limitations to this study that should be considered when discussing the results. First, our survey method reflects the respondents' subjective perception of the questions being investigated. Subjective data has some inherent disadvantages that are hard to avoid in surveys [59]. Our data is collected over a single period of productional data do not allow a dynamic assessment of changes in students' intentions and related behaviours regarding their college admissions, which may affect their applicability [60]. The intentional sampling method has certain limitations, not fully reflecting population characteristics [61]. Our survey was conducted within a cultural context of Vietnam and therefore requires more general statements that can be made by applying the development research model and research conclusions to other countries. Other countries and cultures. The ability to control factors of studying abroad has a positive and significant impact on the intention to study abroad.

\section{CONCLUSIONS}

In recent years, the number of Vietnamese students studying abroad has increased. However, some studies have only found push and pull factors related to the decision to study abroad. This study is a quantitative study examining the relationship between planned behaviour, family cohesion and intention to study in university of Vietnamese students. The research results show that Vietnamese students' intention to university is affected by attitudes towards behaviour, subjective norms, and perceived behavioural control. These findings are consistent with studies applying the theory of planned behaviour to predict individual behavioural intentions [15], [17]. In addition, this study also found a relationship between family cohesion (cohesion) and intention to study at the university of Vietnamese students. These findings have contributed to enriching the research literature applying the theory of planned behaviour in studying the intention to study abroad. The conclusions of this study provide useful information for study abroad management agencies, universities, businesses, and organizations providing study abroad consulting services. It should be recalled that the sample size in this study was small. Therefore, it would be beneficial to repeat this study using a larger sample group from a more diverse population. The limitations of the convenient sampling method have certain limitations, so it is necessary to use the random probability sampling method to limit errors in the prediction.

APPENDIX

APPENDIX I: ITEMS IN THE QUESTIONNAIRE

\begin{tabular}{|c|c|c|c|c|c|c|}
\hline $\begin{array}{c}\text { Code } \\
\text { Atitude }\end{array}$ & Content & \multicolumn{5}{|c|}{$\begin{array}{c}\text { Disagree strongly }=1 ; \text { Disagree a little }=2 ; \text { Neither agree } \\
\text { nor disagree }=3 ; \text { Agree a little }=4 ; \text { Agree Strongly }=5\end{array}$} \\
\hline Ati1 & Studying abroad will improve my foreign language skills & 1 & 2 & 3 & 4 & 5 \\
\hline Ati2 & $\begin{array}{l}\text { The academic reputation of foreign universities is higher than that } \\
\text { of Vietnamese universities }\end{array}$ & 1 & 2 & 3 & 4 & 5 \\
\hline Ati3 & $\begin{array}{l}\text { An international university degree is more valuable than that in } \\
\text { Vietnam }\end{array}$ & 1 & 2 & 3 & 4 & 5 \\
\hline Ati4 & $\begin{array}{l}\text { Studying abroad will give me the opportunity to get a job there } \\
\text { after graduating }\end{array}$ & 1 & 2 & 3 & 4 & 5 \\
\hline Ati5 & $\begin{array}{l}\text { Graduating from foreign universities will expand my career } \\
\text { opportunities when I return to Vietnam }\end{array}$ & 1 & 2 & 3 & 4 & 5 \\
\hline Ati6 & $\begin{array}{l}\text { Having a university degree abroad will help me get a job with a } \\
\text { high salary }\end{array}$ & 1 & 2 & 3 & 4 & 5 \\
\hline Norm & The influence of those around me on & inte & stu & bro & & \\
\hline Nor1 & My parents have a great influence on my university enrollment & 1 & 2 & 3 & 4 & 5 \\
\hline Nor2 & $\begin{array}{l}\text { Other members of my family have a great influence on my } \\
\text { university enrollment }\end{array}$ & 1 & 2 & 3 & 4 & 5 \\
\hline Nor4 & My friends' opinions influenced on my university enrollment & 1 & 2 & 3 & 4 & 5 \\
\hline Nor5 & $\begin{array}{l}\text { My decision to enroll in university abroad was influenced by } \\
\text { international alumni }\end{array}$ & 1 & 2 & 3 & 4 & 5 \\
\hline Nor6 & $\begin{array}{l}\text { May be I will study at a school where my friends / relatives will } \\
\text { study (or be studying) }\end{array}$ & 1 & 2 & 3 & 4 & 5 \\
\hline Control & The ability to control the factors that influ & ce $m$ & iot & i & & \\
\hline Con 1 & $\begin{array}{l}\text { Tuition is an important factor that influences my university } \\
\text { enrollment }\end{array}$ & 1 & 2 & 3 & 4 & 5 \\
\hline Con2 & $\begin{array}{l}\text { Living expenses is an important factor that influences my } \\
\text { university enrollment }\end{array}$ & 1 & 2 & 3 & 4 & 5 \\
\hline Con3 & $\begin{array}{l}\text { The length of the course is an important factor that influences my } \\
\text { university enrollment }\end{array}$ & 1 & 2 & 3 & 4 & 5 \\
\hline Con4 & The convenience of maintaining regular contacts with my relatives & 1 & 2 & 3 & 4 & 5 \\
\hline
\end{tabular}




\begin{tabular}{|c|c|c|c|c|c|c|}
\hline $\begin{array}{c}\text { Code } \\
\text { Atitude }\end{array}$ & My attitude towards studying abroad & \multicolumn{5}{|c|}{$\begin{array}{c}\text { Disagree strongly }=1 ; \text { Disagree a little }=2 ; \text { Neither agree } \\
\text { nor disagree }=3 ; \text { Agree a little }=4 ; \text { Agree Strongly }=5\end{array}$} \\
\hline Atitude & is an important factor that influences my university enrollment & & & & & \\
\hline Con5 & $\begin{array}{l}\text { I think I will have difficulty communicating because of the } \\
\text { language difference if I study abroad }\end{array}$ & 1 & 2 & 3 & 4 & 5 \\
\hline Con6 & $\begin{array}{l}\text { Entrance examinations of prestigious universities in Vietnam are } \\
\text { very competitive so I want to study abroad }\end{array}$ & 1 & 2 & 3 & 4 & 5 \\
\hline Intent & \multicolumn{6}{|c|}{ My intention to studying abroad } \\
\hline Int 1 & I have considered going to study abroad & 1 & 2 & 3 & 4 & 5 \\
\hline Int 2 & I am very interested in studying abroad & 1 & 2 & 3 & 4 & 5 \\
\hline Int3 & I expected to study abroad & 1 & 2 & 3 & 4 & 5 \\
\hline Int4 & I try to study abroad in the future & 1 & 2 & 3 & 4 & 5 \\
\hline Int5 & I intend to study abroad & 1 & 2 & 3 & 4 & 5 \\
\hline Int6 & My family forced me to study abroad & 1 & 2 & 3 & 4 & 5 \\
\hline Cohension & \multicolumn{6}{|c|}{ Cohesion } \\
\hline Cohension 1 & In our family we really help and support each other. & 1 & 2 & 3 & 4 & 5 \\
\hline Cohension 2 & In our family we spend a lot of time doing things together at home & 1 & 2 & 3 & 4 & 5 \\
\hline Cohension 4 & In our family there is a feeling of togetherness & 1 & 2 & 3 & 4 & 5 \\
\hline Cohension5 & My family members really support each other & 1 & 2 & 3 & 4 & 5 \\
\hline Cohension6 & I am proud to be a part of our family & 1 & 2 & 3 & 4 & 5 \\
\hline Cohension 7 & In our family we really get along well with each other & 1 & 2 & 3 & 4 & 5 \\
\hline Cohension 8 & In our family we do things for each other without being asked & 1 & 2 & 3 & 4 & 5 \\
\hline
\end{tabular}

APPENDIX II: TOTAL VARIANCE EXPLAINED

\begin{tabular}{|c|c|c|c|c|c|c|c|c|c|}
\hline \multirow[b]{2}{*}{ Component } & \multicolumn{3}{|c|}{ Initial Eigenvalues } & \multicolumn{3}{|c|}{ Extraction Sums of Squared Loadings } & \multicolumn{3}{|c|}{ Rotation Sums of Squared Loadings } \\
\hline & Total & $\begin{array}{c}\% \text { of } \\
\text { Variance }\end{array}$ & Cumulative $\%$ & Total & $\%$ of Variance & Cumulative $\%$ & Total & $\%$ of Variance & Cumulative $\%$ \\
\hline 1 & 11.319 & 35.371 & 35.371 & 11.319 & 35.371 & 35.371 & 6.125 & 19.140 & 19.140 \\
\hline 2 & 2.756 & 8.613 & 43.983 & 2.756 & 8.613 & 43.983 & 3.954 & 12.357 & 31.497 \\
\hline 3 & 2.372 & 7.414 & 51.397 & 2.372 & 7.414 & 51.397 & 3.435 & 10.735 & 42.233 \\
\hline 4 & 1.902 & 5.944 & 57.341 & 1.902 & 5.944 & 57.341 & 3.370 & 10.531 & 52.763 \\
\hline 5 & 1.762 & 5.508 & 62.848 & 1.762 & 5.508 & 62.848 & 3.227 & 10.085 & 62.848 \\
\hline
\end{tabular}

Extraction Method: Principal Component Analysis.

\section{REFERENCES}

[1] Le Thu. (March 2019). The number of Vietnamese students is 6th in the US. https://duhoc.dantri.com.vn/du-hoc/viet-nam-dung-thu-6-ve-soluong-du-hoc-sinh-tai-my-2018111707381218.htm

[2] Ashwill, M. (May 2018). Viet Nam Ranks 5th in International Enrollment in 3 Countries [translate from Vietnamese]. https://markashwill.com/2018/05/16/viet-nam-ranks-5th-internationalenrollment-in-3-countries/

[3] Mazzarol, T., \& Soutar, G. N, Push-pull" factors influencing international student destination choice. International Journal of Educational Management, 16(2), 2002, pp. 82-90.

[4] Liu, D., \& Morgan, W. J, Students' decision-making about postgraduate education at $\mathrm{G}$ University in China: The main factors and the role of family and of teachers. The Asia-Pacific Education Researcher, 25(2), 2016, pp. 325-335.

[5] Douglas W. Naffziger, Jennifer P. Bott, Carolyn B. Mueller, Factors influencing study abroad decisions among college of business students. International Business: Research Teaching and Practice, 2008 2(1) pp.39-52

[6] Leung, SE, Vietnam: an economic survey. Asian-Pacific Economic Literature, Vol. 24, No. 2, 2010, pp. 83-103.

[7] World Bank. (November 2015), Vietnam, http://data.worldbank.org/ country/ Vietnam.

[8] World Bank. (April 2008). Vietnam: Higher education and skills for growth. World Bank. https://openknowledge.worldbank.org/ handle/10986/7814.

[9] Harman, G, Hayden, M \& Nghi, PT, Higher education in Vietnam: reform, challenges and priorities. Springer, The Netherlands, 2010, pp 19-26.

[10] Welch, A, Ho Chi Minh meets the market: Public and private higher education in Viet Nam. International Education Journal: Comparative Perspectives, Vol. 8, No. 3, 2013, pp. 35-56.

[11] Manpower Group (May 2011), Building a high-skilled economy: A new Vietnam,http://projects.vef.gov/followupresearch/upload/BuildingAHi gh-SkilledEconomy_TheNewVietnam_A4.pdf.

[12] Doherty, B., \& Evershed, N. (March 2018). The changing shape of Australia's immigration policy, The Guardian. Retrieved from https://www.theguardian.com/australia-news/2018/mar/24/australiasfierce- immigration-debate-is-about-to-get-louder.
[13] Kritz, M. M. Globalization of higher education and international student mobility. Comparative Education Review, 57(4), 2012, pp 609-636.

[14] Ajzen, I, From intentions to actions: a theory of planned behavior. In J. Kuhl \& J. Beckmann (Eds.), Action-control: From cognition to behavior, Heidelberg: Springer, 1985, pp. 11-39.

[15] Ajzen I, Madden TJ, Prediction of goal-directed behavior: attitudes, intentions, and perceived behavioral control. J Exp Soc Psychol 22(5), 1986, pp. 53-474.

[16] Ajzen, I, Attitudes, traits, and actions: dispositional prediction of behavior in personality and social psychology. Adv Exp Soc Psychol 20 (1), 1987, pp.1-63.

[17] Ajzen, I, The theory of planned behavior. Organizational Behavior and Human Decision Processes, 50 (1991), 179-211.

[18] Ajzen, I, Predicting and changing behavior: The reasoned action approach. New York: Psychology Press,2010, pp15-19 .

[19] Ajzen, Icek, Behavioral Interventions: Design and Evaluation Guided by the Theory of Planned Behavior, in Social Psychology and Evaluation, edited by M.M. Mark, S.I. Donaldson, and B. Campbell. New York: Guilford Press, 2011, pp. 75-103

[20] Edberg, Mark, Individual Health Behavior Theories in Essentials of Health Behavior: Social and Behavioral Theory in Public Health. 2nd ed. Burlington: Jones \& Bartlett Learning, 2015 Pp. 37-52.

[21] Bloom L, Intentionality and theories of intentionality in development. Hum Dev 43(3), 2000,178-185.

[22] Warshaw PR, Davis FD, Self-understanding and the accuracy of behavioral expectations. Personal Soc Psychol Bull, 10(1), 1984, pp. 111-118.

[23] McEachan, C., Conner, M., Taylor, N., \& Lawton, R. (2011) Prospective prediction of health-related behavior with the TPB: a metaanalysis. Health Psychology Review 5(2), 2011, pp. 97-144.

[24] Ajzen, Perceived behavioral control, self-efficacy, locus of control, and the theory of planned behavior. Journal of Applied Social Psychology, 32 (2002) pp. 665-683.

[25] Nchise, An Empirical Analysis of the Theory of Planned Behavior, A Review of Its Application on E-democracy Adoption Using the Partial Least Squares Algorithm, 4(2), 2012, pp. 171-182.

[26] Jokonya, Osden, Validating Technology Acceptance Model (TAM) during IT Adoption in Organizations, . 10.1109/CloudCom. 2015(56), pp. 509-516.

[27] Hartwell, S. W., \& Benson, P. R, Social integration: A conceptual overview and two case studies. In W. R. Avison, J. D. McLeod, \& B. 
Pescosolido (Eds.), Mental health, social mirror New York: Springer, 2007, pp. 329-353.

[28] Kawachi, I., \& Berkman, L. F, Social ties and mental health. Journal of Urban Health-Bulletin of the New York Academy of Medicine, 78, 2001, pp.458-467

[29] Aquilino WS, From adolescent to young adult: A prospective study of parent-child relations during the transition to adulthood. Journal of Marriage and the Family. 1997; 59, pp.670-686.

[30] [30] McHale, SM.; Crouter, AC, The family contexts of children's sibling relationships. In: Brody, GH., editor. Sibling relationships: Their causes and consequences. Norwood, NJ: Ablex Publishing Corporation; 1996, pp. 173-195.

[31] Arnett JJ. Emerging adulthood: A theory of development from the late tends through the twenties. American Psychologist. 2000; 55:469-480.

[32] Bandura, A, Social learning theory. Englewood Cliffs, NJ: Prentice Hall, 1997, pp152-169.

[33] Whitbeck L, Hoyt D, Huck S, Early family relationships, intergenerational solidarity, and support provided to parents by adult children. Journals of Gerontology: Social Sciences, 49, 1994, pp. S85S94.

[34] Ainsworth, MDS, Attachment: Retrospect and prospect. In: Parkes, CM.; Stevenson-Hinde, J., editors. The place of attachment in human behavior. New York: Basic Books; 1982. pp. 3-30.

[35] [35] Hazen C, Shaver PR, Romantic love conceptualized as an attachment process. Journal of Personality and social Psychology, 52, 1987, pp. 511-524.

[36] Belsky J, Jaffee S, Hsieh K, Silva P, Child-rearing antecedents of intergenerational relations in young adulthood: A prospective study. Developmental Psychology. 2001; 37, pp. 801-813.

[37] Aquilino, WS, Family relationships and support systems in emerging adulthood. In: Arnett, JJ.; Tanner, JL., editors. Emerging adults in America: Coming of age in the 21 st century. Washington, DC: American Psychological Association; 2006. pp. 193-217.

[38] Pimpa, N, The Influence of Family on Thai Students' Choices of International Education. International Journal of Educational Management, 17(5), 2003, pp. 211-219.

[39] Muhammad Safuan, Y., Irma Wani, O., Rudy, A.R., \& Norazah, M.S, Masa Depan Kerjaya, Perhubungan Kekeluargaan dan Pengangan Hidup sebagai Motif Ekspatriasi Akademik Ekspatriat Berdikari di Universiti Islam Antarabangsa Malaysia. Labuan e-Journal of Muamalat and Society, 10 (2016), 101-114.

[40] Moogan, Y. J., Baron, S., and Harris, K, Decision-Making Behaviour of Potential Higher Education Students. Higher Education Quarterly, 53(3), 1999, 211-228

[41] Yang, M. (2007). What attracts mainland Chinese students to Australian higher edu- cation? Studies in Learning, Evaluation, Innovation and Development, 4(2), 2007, pp. 1-12.

[42] Petruzzellis, L., and Romanazzi, S, Educational Value: How Students Choose University: Evidence from An Italian University. International Journal of Educational Management, 24(2), 2010, pp. 139-158.

[43] Muhammad Safuan, Y., Irma Wani, O., Norazah, M.S., Rudie, A.R, Kerjaya Dan Ekonomi Sebagai Motif Ekspatriasi Ekspatriat Akademik Di Institusi Pengajian Tinggi Awam Malaysia. Labuan e-Journal of Muamalat and Society, 9 (2015), 36-47.

[44] Lee, C.K.C., and Morrish, S.C, Cultural Values and Higher Education Choices: Chinese Families. Australasian Marketing Journal, 20, 2012, pp.59-64

[45] Dang Thanh Nhan, Career orientation for children. Family and Gender Studies Journal, N.5 (2010), 27-38.

[46] Nguyen, H. C. (2013). Vietnamese international student mobility: past and current trends. Asian Education \& Development Studies, 2(2), (2013), pp.127-148.

[47] Hair, J., Black, W., Babin, B., and Anderson, R. Multivariate data analysis (7th ed.): Prentice-Hall, Inc. Upper Saddle River, NJ, USA 2010. matic Research, 77(4), 2014, pp. 287-95. https://doi.org/10.1016/j.jpsychores.2014.07.001 PMID: 25280826

[48] Cortina, J. M, What is coefficient alpha? An examination of theory and applications. Journal of applied psychology, 78(1), 1993, pp98.

[49] Hair, J., Anderson, R., Tatham, R. and Black, W, Multivariate data analysis, 5th Edition, Prentice Hall, New Jersey, May, 1998.

[50] Crowley, S. L., \& Fan, X. (1997). Structural equation modeling: Basic concepts and applications in personality assessment research. Journal of Personality Assessment, 68(3), 508-531. https://doi.org/10.1207/s15327752jpa68034

[51] Kline, R.B, Principles and Practice of Structural Equation Modeling Guilford Press, New York, 2011, pp. 142-167.

[52] Nachtigall, C., Kroehne, U., Funke, F., \& Steyer, R, (Why) should we use SEM? Pros and cons of structural equation modeling. Methods of Psychological Research Online, 8(2),2003, pp.1-22.
[53] Ullman, J. B. Structural equation modeling: Reviewing the basics and moving forward. Journal of Personality Assessment, 87(1), Jan 2006, pp 35-50.

[54] Widaman. F., \& Reise, S. P, Exploring the measurement invariance of psychological instruments: Applications in the substance use domain In K. J. Bryant, M. Windle, \& S. G.West (Eds.), The science of prevention: Methodological advances from alcohol and substance abuse research Washington, DC: American Psychological Association, 1997, pp. 281-324.

[55] Bentler, P. M. (July 1990). Comparative fit indexes in structural models. Psychological Bulletin,107, 238-246. https://doi.org/10.1037/0033-295X.86.5.452

[56] Hu, L. T., \& Bentler, P. M, Cutoff criteria for fit indexes in covariance structure analysis: Conventional criteria versus new alternatives. Structural Equation Modeling: A Multidisciplinary Journal, 6(1), 1999, $1-55$.

[57] Phan Anh Tu, Trinh Thuy Hang, Research the factors affecting the intention of studying abroad after graduating of university of economics students in Can Tho University. Can Tho University Journal of Science. 46d, 2016, pp. 122-129.

[58] Ho Quoc Tuan. (September 2017). Story "fad" to study abroad. [Translated from origina Vietnamese].https://www.thesaigontimes.vn/ 264943/chuyen-mot-du-hoc.html

[59] Pakpour AH, Gellert P, Asefzadeh S, Updegraff JA, Molloy GJ, Sniehotta FF, Intention and planning predicting medication adherence following coronary artery bypass graft surgery. Journal of Psychoso-

[60] Xin Z, Liang M, Zhanyou W, Hua X, Psychosocial factors influencing shared bicycle travel choices among Chinese: An application of theory planned behavior. PLOS ONE 14(1), 2019, e0210964.

[61] Lin CY, Updegraff JA, Pakpour AH, The relationship between the theory of planned behavior and medi- cation adherence in patients with epilepsy. Epilepsy \& Behavior, 61, 2016, pp. 231-236.

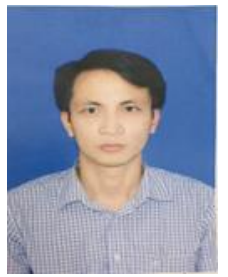

Phuong Huu Tung was born in 1985. Tung holds a master's degree in Economic Management in 2013. completed my $\mathrm{PhD}$ program in Economic Management in 2018. Currently, I am qualified to advise and guide Master's students. PhD student majoring in Economic Management, Business Administration, Human Resource Management, Economics. I am a researcher interested in State management of human resources, human resource development; Education and human personality development; as well as issues related to human resource management in the organization. I have published ten international scientific articles related to Economics, human resource management; school education. I have also published 12 reference books, monographs, training textbooks for Hanoi University of Home Affairs and the Ministry of Education and Training. I have also received several awards for scientific research: outstanding achievements in scientific research from 2017 to 2020; received the Vietnam National Talented Young Scientist Award in 2020 .

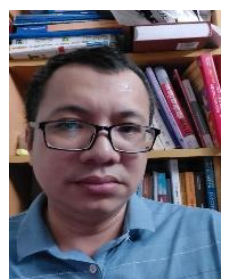

Nguyen Nghi Thanh was born in 1977. He obtained a PhD in Religious Studies from the Vietnam Academy of Social Sciences. He is currently Deputy Editor-in-Chief of the Journal of Interior Science. Dr. Thanh is qualified to supervise doctoral students. His main research interests are Religion, Philosophy Education school; Social sciences and humanities. He has carried out many research projects at ministerial level, is a key member in a number of nationa projects. He has published two books and more than 10 articles on religious studies, the relationship between mindfulness of the five precepts and wellbeing, happiness, motivation, and other variables. I have the ability to do quantitative research and regression models, analyze data. Currently, every month, I still edit dozens of articles submitted to the Journal of Internal Affairs, which is my favorite job.

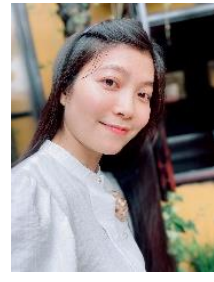

Nguyen Anh Nguyet was born in 1983. She graduated with a master's degree in Journalism and Communication in 2015. Currently, she is a $\mathrm{PhD}$ student at the Institute of Journalism - Academy of Journalism and Communication. As a researcher interested in the fields such as journalism, education, training, as well as issues related to relationships in family and society, she has published many domestic scientific articles, participating in publishing some monographs, textbooks, being the head of scientific research projects funded by Hanoi University of Home Affairs and the Ministry of Home Affairs. 